\title{
Career Guidance through Multilevel Expert System Using Data Mining Technique
}

\author{
Dr. Gufran Ahmad Ansari \\ Department of Information Technology, College of Computer, Qassim University, \\ Qassim,Kingdom of Saudi Arabia (KSA) \\ E-mail: gufranansari@qu.edu.sa
}

Received: 05 March 2017; Accepted: 17 April 2017; Published: 08 August 2017

\begin{abstract}
In this paper, the author provides a framework for Multilevel Expert System to advice scholars for their future career. The proposed framework aims at providing information to decide the career paths for the academics. The emerging fields of Expert System, Education, and Data Mining are speedily providing new possibilities for collecting, analyzing and guiding the scholars in their careers. Many scholars suffer from taking a right career decision, only a few scholars took the right decision about their careers. A poor career decision of scholars may push his whole life in the dark. Nowadays selecting a right career becomes very difficult for the scholars. Among the works reported in this field, we concentrate only Experts Systems that deal with scholar's career selection problem through Data Mining technique
\end{abstract}

Index Terms-Scholars, Career, Education, Expert System, Data Mining.

\section{INTRODUCTION}

Career guidance can be defined as a procedure by which scholars knows about their work, career opportunity and prepare themselves for those opportunities. Career guidance is the method that will help to the scholars to recognize and know yourself and the world of work in order to build the career, educational, and life decisions. In this paper, authors discuss and recommended that community strategy and legislation be twisted to allow career guidance to go onward as a foremost strength in human capital growth. The large amount career research has paying to attention on career growth and career alternative rather than the process and efficacy of career guidance and counseling [1-3]. Career psychology has a long-standing concentration in exploring the individual uniqueness that permits people to successfully manage their careers and incorporate their self-concept into their operational responsibility. Emerging from the previous concepts of career maturity and the proposal of career adaptability idea is getting more attention as a serious assembles in this point of view. In its most recent conceptualization, career flexibility refers to psychosocial assemblies that indicate an individual's resources for the deal with current and predictable tasks, in their professional roles [4-6]. Career guidance is an ultimate procedure that, whether you are familiar with it or not, in fact, this is ongoing process when you were born. There are a number of issues that influence your career growth, including your welfare, skills, standards, behavior, environment, and conditions. The Human Resource Development agenda have to let the scholars should start the design, develop and implement a career system that formulates the achievement of developmental strategy in all the sectors-local, regional and national levels. Through the accurate career guidance, scholars can successfully manage their career and participate in building a society and a healthy nation. Generally, the scholars needed career guidance in many stages but mainly guidance starts with primary level guidance, then proceeds to secondary level guidance and finally at higher level guidance which is shown as "Fig. 1" given below;

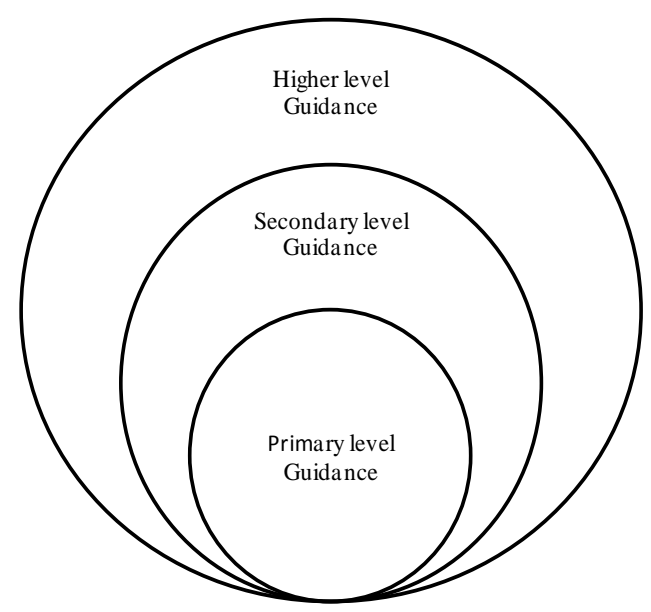

Fig.1. General Career Level Guidance System

In "Fig. 1" the small circle shows the primary level guidance to the scholars and it's easy to level guidance, middle -level circle shows the secondary level guidance for the scholars which is hard than primary level guidance and finally biggest circle shows the high-level guidance for the scholars that means complex problem that is not solved by first two level.

An Expert System can describe as a computer program that employs artificial intelligence to resolve computer associated troubles within the specific field which is generally necessary for person use. The most important 
objective of Expert System is to be aware of intelligence by constructing computer programs that show the intelligence activities, it is anxious through an idea that process representative inference through the system and how the information use to make those inferences will be characterized [7-8].The expert systems skill broadly accepted by IT development companies. Expert System is a type of application which is executed in the system where it can recall when it needed and does the work as an expert work and gives guidance to the scholars as an expert [9].One of the main requirements for designing an expert system is knowledge of database an entity, which study and understand the database and how human expert are making decisions and interpret the rules into terms that computer can recognize and complete the task. The key idea of expert systems is to give a professional advice when scholar looking a guidance from a system for their career. Through this kind of system application scholars can replicate their actions [10].

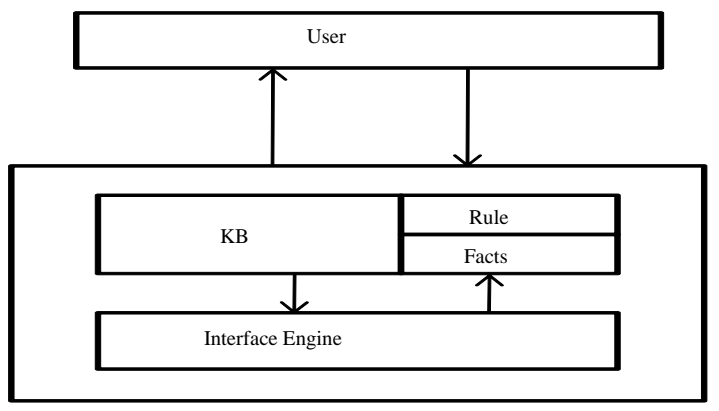

Fig.2. General Architecture of an Expert system

"Fig. 2" given above shows the general architecture of Expert System (ES).The formation of information is known as the field of ES. Generally, there are three main important mechanisms of ES that can be recognized as a Knowledge base (KB), Inference Engine (IE) and User (U) [11-12].This knowledge basically holds the domain knowledge which is in work by the inference engine to describe wrapping up. Generally, knowledge obtains from human export through meeting and explanation after that this knowledge frequently represented in the form of IF-THEN rules. The area of education is an extremely active and demanding area to apply the above techniques. Career guidance is required by the scholars but did not get the guidance through the system then Expert System retrieves the scholar's query from the database and sends this query to an expert domain and expert domain will add the guidance in the system.

Data mining can be defined as database mining or Knowledge Discovery in Databases (KDD) that aim to find out useful information from the large datasets. Data mining is taking out of unknown information from the large database. This is a commanding new technology with big potential which facilitates organizations to the center of attention on the most important business process information in their data warehouses [13-14]. Occasionally data mining is also known as a knowledge discovery. Knowledge discovery is the method of analyzing data from various viewpoints and shortening it into meaningful and helpful information. Data Mining has been fruitfully implemented to many real world demanding problems. As a result, data mining has become accepted as a business intelligence tool with the huge development projection [15]. Despite the fact that there are many data mining techniques, most of the work that has been done in education that falls into the group of classification, clustering, visualization, and association analysis etc. [16-19].

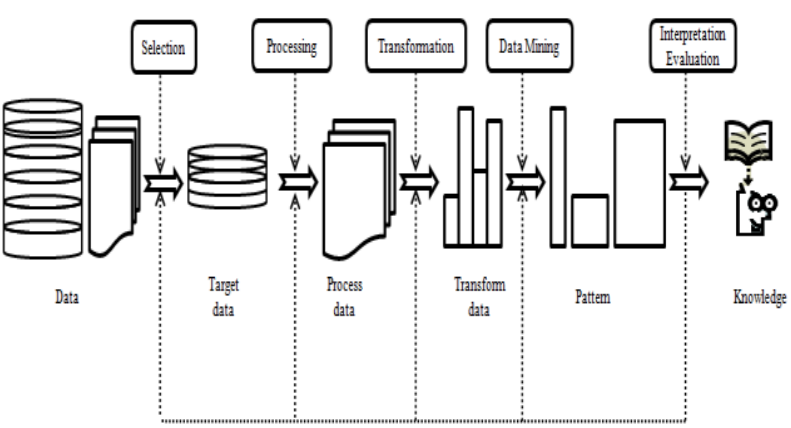

Fig.3. General structure of Data mining process to build up knowledge

"Fig. 3" Shows the general structure of Data Mining process which builds up knowledge. In this figure, target data is selected from the database. After selecting the target data it process and transform to apply data mining using pattern and executes the pattern for the estimation to convert the data into knowledge. The knowledge base is capable of utilizing the brainpower of the system as given essential information for assembling policies are controlled in the knowledge base system. This information is applied as a foundation of a set of laws for the system [20].

\section{Proposed CAREer Guidance MultileVEl EXPERT SYSTEM FRAMEWORK FOR SCHOLARS}

In our proposed system, Career Guidance Multilevel Expert System, the complete career guidance for the scholar is shown in Figure 4 Given. In our proposed Career Guidance Multilevel Expert System, the complete guidance for the needy scholars is shown in Figure 4. For any level, of career guidance like Primary level, Secondary level, and higher level, the scholars first needed to enter the system and select the level of guidance and then the system search matching guidance in the system database for the scholar's query. If system found the guidance information in the database then system gives this guidance to the scholars and if not found guidance information into the system database then system will go for the Domain Specific problem guidance level and find out the problem level is related with Simple Problem, Technical Problem or Complex problem. After finding the complexity of the problem, problem specification will be given to the domain experts. A domain expert will identify and add the knowledge for the new guidance problem. The new rules and facts will be added to the database. After doing this the system will search again in the database and found the new solution 
the scholar's query and provide the similar guidance to the scholars.

The contribution of this paper can be summarized as follows:

- Design a Career Guidance Multilevel Expert System Framework for Scholars

- Quantization of factors

- Use of Machine Learning (ML) technique for discovering connection between factors and this is very useful for large database

The rest of the paper is organized as follows: Sections II provide a proposed career guidance multilevel expert system for scholars and discuss the framework in details. Section III illustrates the experimental study. Finally, section IV deals results and conclusion of scholar's queries.

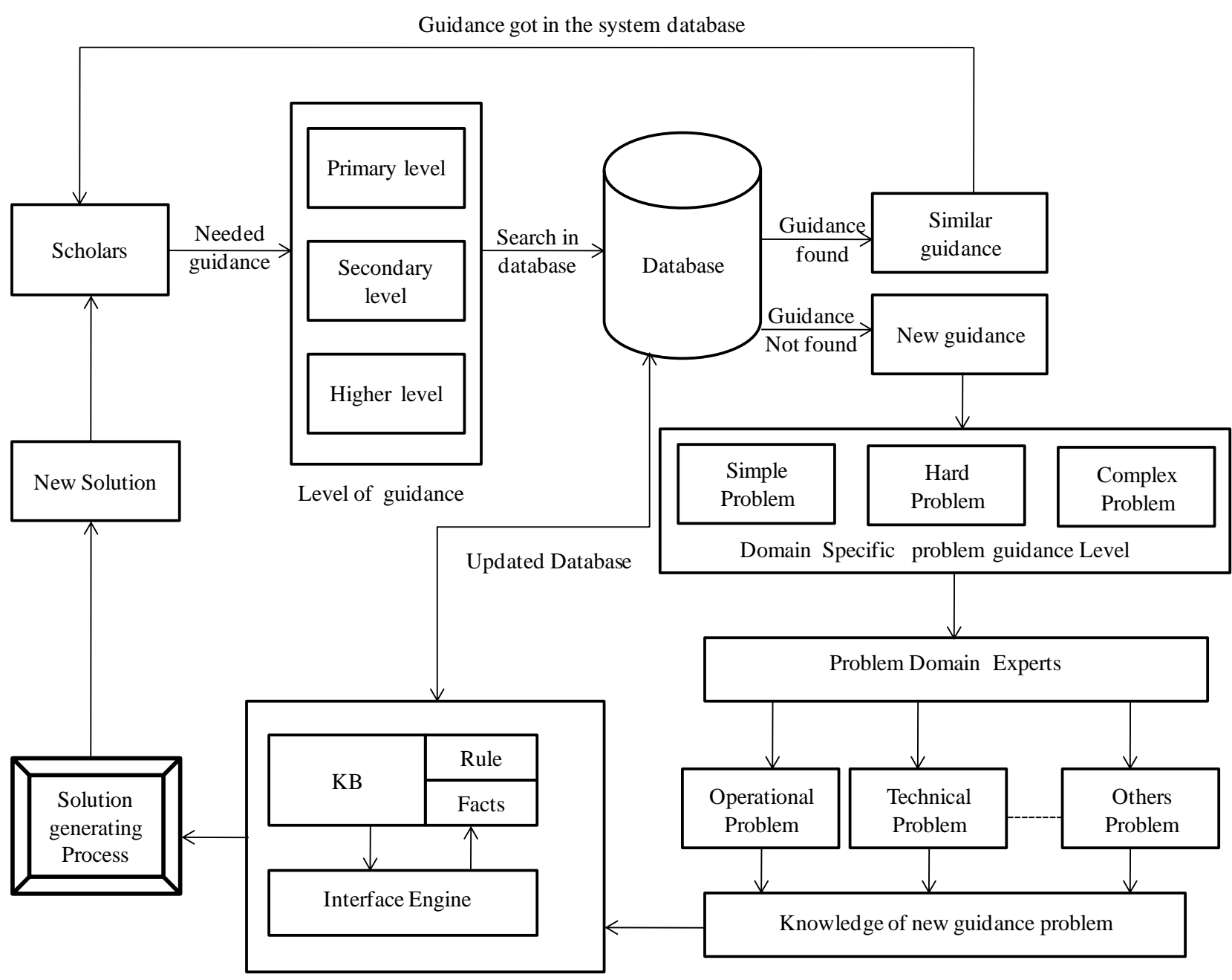

Fig.4. Career Guidance Multilevel Expert System Framework for Scholars

\section{EXPERIMENTAL STUDY}

Table 1 shows the different influencing career guidance factors which influence scholar's career decision. These influencing factors are very important for the scholars in selecting the precise career. In this table, each influencing factor with their meaning and their influence are given and each influencing factor has a numerical weight and this numerical weight is consider for scoring the different scholar's selection factors. All factors have minimum one and maximum five value, scholars can select any value between it. These values are given by the scholars and that wants the advice from the system then system matched these values for the system database and advice the precise guidance to the scholars $[21,22]$. 
Table 1. Influencing Career Guidance Factors

\begin{tabular}{|c|c|c|c|c|c|c|c|}
\hline \multirow[b]{2}{*}{ S. No. } & \multirow[b]{2}{*}{ Factors } & \multirow[b]{2}{*}{ Meanings } & \multicolumn{5}{|c|}{ Score Rubrics } \\
\hline & & & $\begin{array}{c}\text { Very Poor } \\
\text { (1) }\end{array}$ & $\begin{array}{c}\text { Poor } \\
(2) \\
\end{array}$ & $\begin{array}{l}\text { Medium } \\
\text { (3) }\end{array}$ & $\begin{array}{c}\text { Good } \\
(4)\end{array}$ & $\begin{array}{c}\text { Excellent } \\
(5) \\
\end{array}$ \\
\hline 1 & $\begin{array}{l}\text { Computer } \\
\text { Skills }\end{array}$ & $\begin{array}{l}\text { Knowledge } \\
\text { of computer }\end{array}$ & $\begin{array}{l}\text { I don't use } \\
\text { computer }\end{array}$ & $\begin{array}{c}\text { I can just } \\
\text { check emails } \\
\text { \& messages }\end{array}$ & $\begin{array}{l}\text { I can use office } \\
\text { Software }\end{array}$ & $\begin{array}{c}\text { I can write software } \\
\text { program }\end{array}$ & $\begin{array}{l}\text { I can design } \\
\text { H/Wand S/W }\end{array}$ \\
\hline 2 & $\begin{array}{c}\text { Office } \\
\text { Experience }\end{array}$ & $\begin{array}{l}\text { Having } \\
\text { experience to } \\
\text { manage the } \\
\text { office activity }\end{array}$ & $\begin{array}{c}\text { I cannot } \\
\text { manage office } \\
\text { activity }\end{array}$ & $\begin{array}{l}\text { I can manage } \\
\text { office use } \\
\text { stationary } \\
\text { activity }\end{array}$ & $\begin{array}{l}\text { I can manage } \\
\text { office use } \\
\text { stationary and } \\
\text { attendance } \\
\text { activity }\end{array}$ & $\begin{array}{l}\text { I can manage office } \\
\text { use stationary, } \\
\text { attendance and HR } \\
\text { activity }\end{array}$ & $\begin{array}{l}\text { I can manage all } \\
\text { activity of office } \\
\text { like } \mathrm{HR}, \mathrm{Mkt}, \mathrm{A} / \mathrm{c} \\
\text { etc. }\end{array}$ \\
\hline 3 & Location & $\begin{array}{c}\text { Place where } \\
\text { he or she can } \\
\text { work }\end{array}$ & $\begin{array}{l}\text { I cannot work } \\
\text { in rural remote } \\
\text { areas }\end{array}$ & $\begin{array}{l}\text { I can work } \\
\text { only in rural } \\
\text { remote areas }\end{array}$ & $\begin{array}{c}\text { I can work in } \\
\text { rural and remote } \\
\text { areas }\end{array}$ & $\begin{array}{l}\text { I can work with } \\
\text { modernity } \\
\text { connected areas }\end{array}$ & $\begin{array}{l}\text { I can work only } \\
\text { metropolitan with } \\
\text { areas }\end{array}$ \\
\hline 4 & $\begin{array}{c}\text { Financial } \\
\text { Status of } \\
\text { money }\end{array}$ & $\begin{array}{l}\text { Capable of } \\
\text { expense in } \\
\text { career }\end{array}$ & $\begin{array}{l}\text { Cannot } \\
\text { expense money }\end{array}$ & $\begin{array}{c}\text { Partially } \\
\text { expense } \\
\text { money }\end{array}$ & $\begin{array}{c}\text { Moderately } \\
\text { expense money }\end{array}$ & $\begin{array}{l}\text { Strongly expense } \\
\text { money }\end{array}$ & $\begin{array}{l}\text { Very strongly } \\
\text { expense money }\end{array}$ \\
\hline 5 & Interest & $\begin{array}{c}\text { Personally } \\
\text { interested } \\
\text { working area }\end{array}$ & $\begin{array}{l}\text { I can work } \\
\text { only my } \\
\text { interest area }\end{array}$ & $\begin{array}{l}\text { I can work } \\
\text { some other } \\
\text { than my } \\
\text { interest area }\end{array}$ & $\begin{array}{l}\text { I can work in } \\
\text { both area }\end{array}$ & $\begin{array}{l}\text { I can work in both } \\
\text { area effectively }\end{array}$ & $\begin{array}{l}\text { I can work in both } \\
\text { area efficiently }\end{array}$ \\
\hline 6 & Age & $\begin{array}{c}\text { Working age } \\
\text { of the } \\
\text { employee } \\
\end{array}$ & $\begin{array}{l}\text { Very old and } \\
\text { very Young }\end{array}$ & $\begin{array}{l}\text { Young and } \\
\text { Old Young }\end{array}$ & $\begin{array}{l}\text { Moderately } \\
\text { young and old }\end{array}$ & Golden age & $\begin{array}{l}\text { Excellent golden } \\
\text { age }\end{array}$ \\
\hline 7 & Parents & $\begin{array}{c}\text { Parents } \\
\text { preference in } \\
\text { selection of } \\
\text { career }\end{array}$ & $\begin{array}{l}\text { Do not agree to } \\
\text { work in rural } \\
\text { areas }\end{array}$ & $\begin{array}{c}\text { Partially } \\
\text { agree to work } \\
\text { in rural areas }\end{array}$ & $\begin{array}{l}\text { Agree to work in } \\
\text { rural areas }\end{array}$ & $\begin{array}{l}\text { Strongly agree to } \\
\text { work in rural areas }\end{array}$ & $\begin{array}{c}\text { Very strongly agree } \\
\text { to work in rural } \\
\text { areas }\end{array}$ \\
\hline 8 & Culture & $\begin{array}{l}\text { Working } \\
\text { culture }\end{array}$ & $\begin{array}{l}\text { Work in local } \\
\text { culture }\end{array}$ & $\begin{array}{l}\text { Work in } \\
\text { regional } \\
\text { culture }\end{array}$ & $\begin{array}{l}\text { Work in regional } \\
\text { and local culture }\end{array}$ & $\begin{array}{l}\text { Work in national } \\
\text { culture }\end{array}$ & $\begin{array}{c}\text { Work in } \\
\text { International } \\
\text { culture }\end{array}$ \\
\hline 9 & $\begin{array}{c}\text { Job } \\
\text { Security }\end{array}$ & Is job secure & $\begin{array}{c}\text { I am not Agree } \\
\text { to work in } \\
\text { private job }\end{array}$ & $\begin{array}{c}\text { Agree to } \\
\text { work in } \\
\text { private job }\end{array}$ & $\begin{array}{c}\text { Agree in semi } \\
\text { Government job }\end{array}$ & $\begin{array}{l}\text { Very Agree in state } \\
\text { Government job }\end{array}$ & $\begin{array}{l}\text { Strongly agree in } \\
\text { Central } \\
\text { Government job }\end{array}$ \\
\hline 10 & $\begin{array}{l}\text { Medical } \\
\text { Insurance }\end{array}$ & $\begin{array}{l}\text { Is medical } \\
\text { insurance } \\
\text { facility } \\
\text { available, }\end{array}$ & Not available & $\begin{array}{c}\text { Partial } \\
\text { available }\end{array}$ & $\begin{array}{l}\text { Available for } \\
\text { employee }\end{array}$ & Available for family & $\begin{array}{l}\text { Available for } \\
\text { family and parents }\end{array}$ \\
\hline 11 & $\begin{array}{l}\text { Children } \\
\text { Schooling }\end{array}$ & $\begin{array}{l}\text { Children } \\
\text { Education }\end{array}$ & $\begin{array}{l}\text { Local level } \\
\text { standard } \\
\text { education }\end{array}$ & $\begin{array}{c}\text { Regional } \\
\text { level standard } \\
\text { education }\end{array}$ & $\begin{array}{l}\text { Regional and } \\
\text { local level } \\
\text { standard } \\
\text { education }\end{array}$ & $\begin{array}{c}\text { National level } \\
\text { standard education }\end{array}$ & $\begin{array}{l}\text { International level } \\
\text { standard education }\end{array}$ \\
\hline
\end{tabular}

For providing precise career guidance to the scholars we consider Table 2 which is showing the influencing career guidance factors with the scholar's score which is used as a sample of measuring scholar's performance. We used data mining model Nearest Neighbor (NN) technique for the implementation of this model. Table 2 is used as a sample scores to match the scholar's score for selecting different career fields. This Table 2. is divided mainly into three important heading and the first headings represent as a scholar that show scholars data, heading two shows the factors and their score and the third heading shows a career field that is selected by the scholar. For every scholar, we match the score with existing database and the career field that find in suggested on the score of the database. We used here the Nearest Neighbor (NN) data mining technique for matching the score of the scholars with the database for finding the precise career field for the new scholars [2325].

Nearest Neighbor $(\mathrm{NN})$ calculates the closest matching object using a formula known widely as Euclidean Distance.

$$
\operatorname{Distance}(d)=\sqrt{\sum_{i=1}^{n}\left(x_{i}-y_{i}\right)^{2}}
$$

Where, $\mathrm{x}_{\mathrm{i}}$ denotes the score of existing influencing career selection factors, $y_{i}$ is the new influencing career selection factors of new scholars. Here, $\mathrm{n}$ denotes the number of total factors. 
Table 2. Sample scoring database for scholars of different career fields

\begin{tabular}{|c|c|c|c|c|c|c|c|c|c|c|c|c|}
\hline \multirow[t]{3}{*}{ Scholars } & \multicolumn{12}{|c|}{ Factors } \\
\hline & 1 & 2 & 3 & 4 & 5 & 6 & 7 & 8 & 9 & 10 & 11 & \\
\hline & 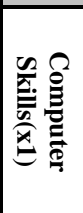 & 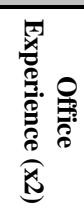 & 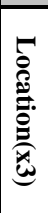 & 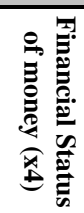 & 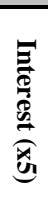 & 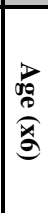 & 苞 & 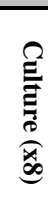 & 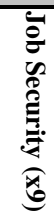 & 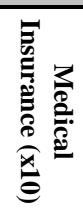 & 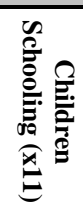 & Career Fields \\
\hline 1 & 3 & 3 & 4 & 2 & 5 & 3 & 4 & 3 & 4 & 3 & 4 & Teaching \\
\hline 2 & 5 & 4 & 3 & 3 & 5 & 5 & 4 & 4 & 2 & 2 & 3 & Technology \\
\hline 3 & 3 & 3 & 3 & 4 & 3 & 3 & 2 & 5 & 4 & 4 & 4 & Airlines \\
\hline 4 & 2 & 1 & 4 & 4 & 4 & 4 & 4 & 5 & 4 & 5 & 4 & Medical \\
\hline 5 & 3 & 5 & 3 & 3 & 4 & 4 & 3 & 4 & 4 & 4 & 4 & Banking \\
\hline 6 & 3 & 4 & 5 & 1 & 4 & 4 & 2 & 5 & 1 & 1 & 1 & Tour and Travel \\
\hline 7 & 3 & 5 & 4 & 4 & 4 & 4 & 3 & 3 & 4 & 3 & 4 & Management \\
\hline 8 & 2 & 4 & 3 & 4 & 2 & 2 & 3 & 3 & 3 & 3 & 4 & Legal law \\
\hline 9 & 3 & 5 & 5 & 3 & 3 & 2 & 2 & 4 & 3 & 3 & 4 & Media \\
\hline 10 & 2 & 4 & 3 & 1 & 5 & 5 & 5 & 4 & 5 & 5 & 4 & Military \\
\hline 11 & 3 & 5 & 4 & 1 & 2 & 3 & 4 & 4 & 4 & 4 & 4 & Office Administration \\
\hline 12 & 2 & 5 & 5 & 3 & 4 & 3 & 4 & 3 & 3 & 4 & 3 & Manufacturing \\
\hline 13 & 2 & 5 & 5 & 1 & 4 & 4 & 5 & 4 & 4 & 3 & 3 & Sales \\
\hline 14 & 1 & 4 & 3 & 3 & 3 & 2 & 5 & 4 & 3 & 3 & 3 & Fishing \\
\hline 15 & 3 & 5 & 4 & 4 & 1 & 2 & 4 & 4 & 4 & 3 & 3 & Finance \\
\hline
\end{tabular}

Table 3. shows the new scholars weight and the score. Also, it shows the career guidance influencing factors in selection career. These new scholars give a numerical the value that will be used in $\mathrm{NN}$ data mining technique for matching and suggesting the scholars career field with existing career field.

Table 3. Sample scoring for a new scholar

\begin{tabular}{|c|c|c|c|c|c|c|c|c|c|c|c|c|}
\hline \multirow{3}{*}{$\begin{array}{l}\text { New } \\
\text { Scholar }\end{array}$} & 1 & 2 & 3 & 4 & 5 & 6 & 7 & 8 & 9 & 10 & 11 & $\begin{array}{l}\text { Suggested } \\
\text { Career field }\end{array}$ \\
\hline & (y1) & $(\mathrm{y} 2)$ & (y3) & (y4) & (y5) & (y6) & (y7) & (y8) & (y9) & (y10) & (y11) & \multirow{2}{*}{ To be decided } \\
\hline & 3 & 2 & 3 & 4 & 3 & 4 & 1 & 3 & 5 & 4 & 3 & \\
\hline
\end{tabular}

Table 4. shows the career measuring score of scholars along with their given weight to each factor and sum of the weight of all factors. This table is basically used for the comparison of a score with the new scholars and nearest matching scholars to suggest the precise career field.

Table 4. Career Measuring Score

\begin{tabular}{|l|l|l|l|l|l|l|l|l|l|l|l|}
\hline $\mathbf{1}$ & $\mathbf{0}$ & $\mathbf{0}$ & $\mathbf{1}$ & $\mathbf{9}$ & $\mathbf{4}$ & $\mathbf{0}$ & $\mathbf{0}$ & $\mathbf{4}$ & $\mathbf{0}$ & $\mathbf{0}$ & $\mathbf{4 . 4}$ \\
\hline $\mathbf{9}$ & 1 & 1 & 4 & 9 & 0 & 0 & 1 & 0 & 1 & 1 & $\mathbf{5 . 2}$ \\
\hline $\mathbf{1}$ & 0 & 1 & 9 & 1 & 4 & 4 & 4 & 4 & 1 & 0 & $\mathbf{5 . 4}$ \\
\hline $\mathbf{0}$ & 4 & 0 & 9 & 4 & 1 & 0 & 4 & 4 & 4 & 0 & $\mathbf{5 . 5}$ \\
\hline $\mathbf{1}$ & 4 & 1 & 4 & 4 & 1 & 1 & 1 & 4 & 1 & 0 & $\mathbf{4 . 7}$ \\
\hline $\mathbf{1}$ & 1 & 1 & 0 & 4 & 1 & 4 & 4 & 1 & 4 & 9 & $\mathbf{5 . 5}$ \\
\hline $\mathbf{1}$ & 4 & 0 & 9 & 4 & 1 & 1 & 0 & 4 & 0 & 0 & $\mathbf{4 . 9}$ \\
\hline $\mathbf{0}$ & 1 & 1 & 9 & 0 & 9 & 1 & 0 & 1 & 0 & 0 & $\mathbf{4 . 7}$ \\
\hline $\mathbf{4}$ & 4 & 1 & 4 & 1 & 9 & 4 & 1 & 1 & 0 & 1 & $\mathbf{5 . 5}$ \\
\hline $\mathbf{1}$ & 1 & 1 & 0 & 9 & 0 & 1 & 1 & 9 & 4 & 0 & $\mathbf{5 . 2}$ \\
\hline $\mathbf{0}$ & 4 & 0 & 0 & 0 & 4 & 0 & 1 & 4 & 1 & 0 & $\mathbf{3 . 7}$ \\
\hline $\mathbf{0}$ & 4 & 1 & 4 & 4 & 4 & 0 & 0 & 1 & 1 & 1 & $\mathbf{4 . 5}$ \\
\hline $\mathbf{0}$ & 4 & 1 & 0 & 4 & 1 & 1 & 1 & 4 & 0 & 1 & $\mathbf{4 . 1}$ \\
\hline $\mathbf{1}$ & 0 & 0 & 1 & 9 & 4 & 0 & 0 & 4 & 0 & 0 & $\mathbf{4 . 4}$ \\
\hline $\mathbf{9}$ & 1 & 1 & 4 & 9 & 0 & 0 & 1 & 0 & 1 & 1 & $\mathbf{5 . 2}$ \\
\hline
\end{tabular}


"Fig. 5" refers to the score for influencing factors for new scholars. Note that, career guidance influencing factors choice score between from 1 to 5 and new scholars need to select all 11 factors for career guidance. Figure 5 shows the score factors for the new scholars and score through the new scholar's score can give the guidance to the scholars.

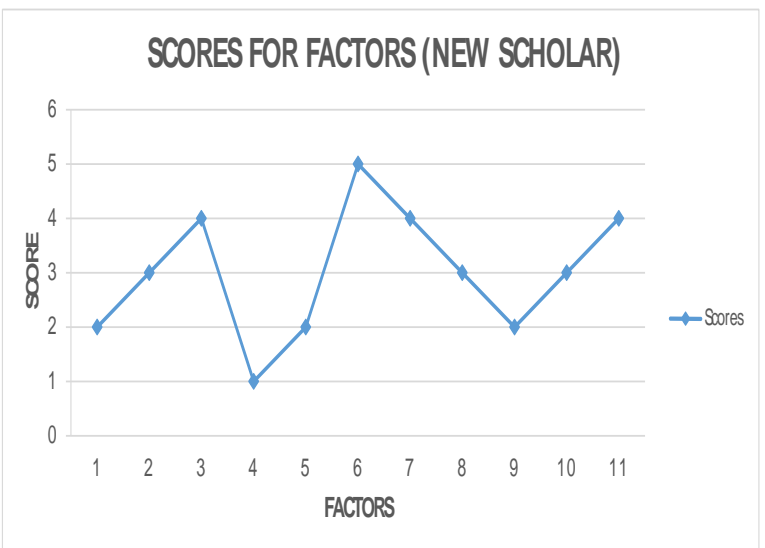

Fig.5. Score factors for new scholars

"Fig.6" shows the matching score with numbers of scholars available in the database. According the matching score system suggested the career field for the new scholars is near to the Office Administration, Manufacturing, Sales, and teaching field can select for career respectively. Medical, Tour and Travel, Media and finance field are not suitable for him if he needs to select the career of any of these fields need to improve their factors as shown in Figure7.

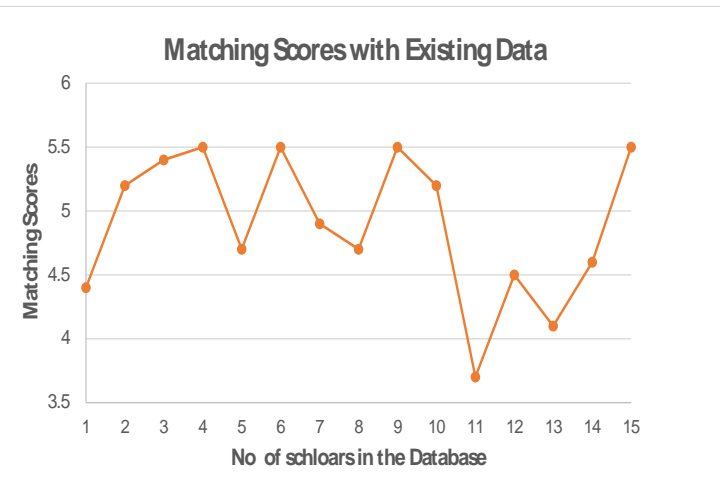

Fig.6. Illustration of the matching score with the existing data

"Fig.7" refers to the score and influencing factors for comparisons score of new scholars and their nearest matching scholars and not nearest career field score. Note that, the blue line shows the new scholars score and the brown line shows the matching scholars score. "Fig.7" shows the comparisons with the nearest matching between new and closet matching scholars and can provide the guidance to the new scholars using this graph. According to the "Fig.7" new scholar's score of its nearest score matching with the system, the score is 4,1 and 5. According to the scholar's score system recommended he can go with the medical career, Teaching Field, and field. Also, the figure shows that 2, 3, 9 and 11 etc. is not a suitable field for their career. Technology, Airlines, Media and office Administration field is not a suitable for the new scholars.

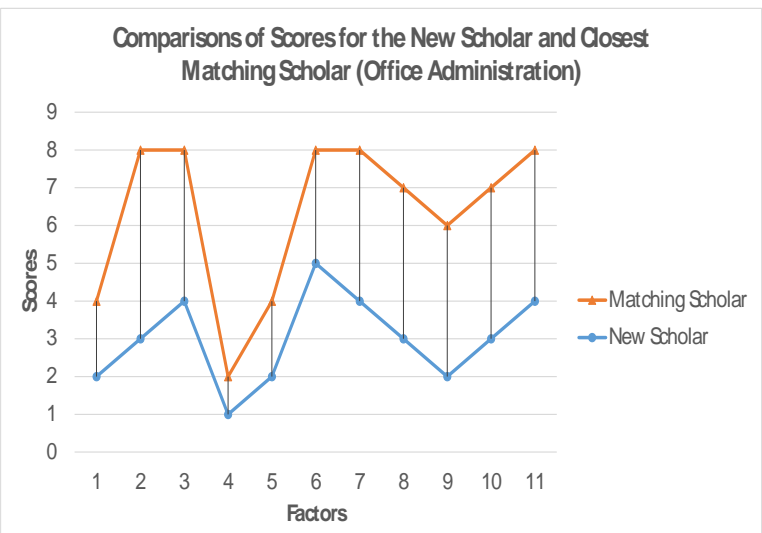

Fig.7. Comparisons of score for the new scholars and closing matching scholars

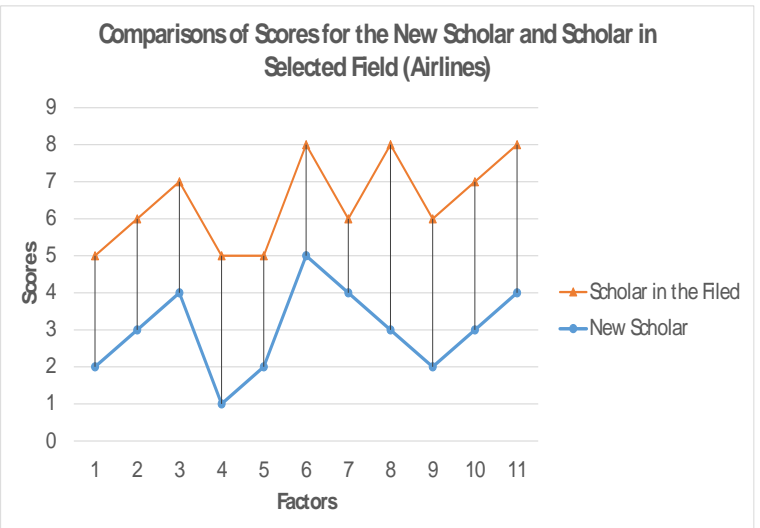

Fig.8. Comparisons of score for the new scholars and scholar in selected field

"Fig. 8" illustrates the comparison score for the new scholar and selected field by the scholars. From Figure 8 one can give the above queries answers like scholars want to make his career in Airlines field and system suggested that for his career management field is better and this is based on the weight given by the scholars. Other queries answer also can be suggested by the system that if he wants the career in Airlines field he need to improve factor 4, 5,9,10 and 11 etc.

\section{RESULTS AND CONCLUSION}

The framework designed in this research paper is evaluated for a case study in educational data mining. In the framework illustrated above, scholars refer to career guidance framework for their bright future guidance. In this work, author uses data collected from a different government university and the private educational institutions in the Kingdom of Saudi Arabia.

The proposed model is suitable for answering many queries related to career guidance. For example, a scholar 
may have queries similar to the ones below:

Q1: Which area is best suitable for my career?

Q2: Which area is not suitable for me?

Q3: I am the good for area $x$ ?

Q4: If I am not good area in $\mathrm{x}$, then which factors I need to improve to go on area $\mathrm{x}$ ?

Q5: I want to make career in this field what factors I need to improve?

These queries and many others can be effectively answered using the proposed model. We have shown in the previous section how some of these queries can be addressed using the case study (ref. Fig 6 to 8). Other queries can be set up and data can be collected to address additional queries from the scholar.

Even though the same case study is accomplished using data from the same university, the procedure describes below is non-specific and can be applied to multiple universities or multiple educational institutions which are run in the different location. For the purpose of confidentiality, the name and ID of scholar's are not mentioned here. Also, author uses the scholar's name as 1 , $2,3 \ldots \ldots$ etc. In this work, data evaluated from a total of 11 career influencing factor containing scholar's records are analyzed. Each scholar's record is a tuple of table 1 that shows some samples of data used in this case study. This research paper has presented a framework for scholars to select a precise career for their good future and this framework is designed with the combination of an expert system and data mining. It is an endeavor to provide the precise career guidance to the scholars. The framework is also implemented with the Data Mining technique. A multiple career influencing factors has been recognized that are important for scholars for career selection. This framework is very helpful for the scholars who especially cannot decide which career is the best for them and which career they can continue as a priority the top career. The applied justification analysis on this study concludes that proposed framework is highly acceptable.

\section{ACKNOWLEDGEMENT}

The author is so grateful to Dr. Mohammad Tanvir Parvez from Qassim University for his valuable suggestions and comments.

\section{REFERENCES}

[1] Herr., "The future of career counselling as an instrument of public policy". The Career development quarterly, 52, $8-17,2003$

[2] Kerry B. Bernes Angela D. Bardick David T. Orr "Career guidance and counselling efficacy studies: an international research agenda" Int J Educ Vocat Guid, Springer Science +Business Media B.V.:81-96, 2007

[3] Dagley, J. C., \& Salter, S. K. "Practice and research in career counselling and development-2003", The Career Development Quarterly, 53, 99-157, 2004

[4] Savickas, M. L., \& Porfeli, E. J. Career Adapt-Abilities Scale: Construction, reliability, and measurement equivalence across 13 countries. Journal of Vocational Behavior, 80(3), 661-673, 2012
[5] Andreas Hirschi, Domingo Valero "Career adaptability profiles and their relationship to adaptivity and adapting" Journal of Vocational Behavior 88: Elsevier, pp. 220-229, 2015

[6] Super, D. E., \& Knasel, E. G. "Career development in adulthood: Some theoretical problems and a possible solution”. British Journal of Guidance and Counselling, 9, 194-201, 1981

[7] C.S. Krishnamoorthy, S. Rajeev, Artificial intelligence and expert systems for engineers. LLC: CRC Press; 1996.

[8] G. A. Ansari "An Adoptive Medical Diagnosis System Using Expert System with Applications" Journal of Emerging Trends in Computing and Information Sciences, Vol. 4, No. 3 Mar 2013

[9] L. M. Laita, G. Gonzlez-Paez, E. Roanes-Lozano, V. Maojo, L. de Ledesma. A methodology for constructing expert systems for medical diagnosis, ISMDA 2001, Crespo, J., Maojo,V., Martin, F. (Eds.), Springer-Verlag, LNCS, (2199):146-152, 2001

[10] J. Bann; G. Irisarri; D. Kirschen; et al., "Integration of Artificial Intelligence Applications in the EMS: Issues and Solutions", IEEE Transactions on Power Systems, Vol. 11, No. 1, pp. 475-482, Feb 1996

[11] M. Ayman Al Ahmar "Rule Based Expert System for Selecting Software Development Methodology", Journal of Theoretical and Applied Information Technology, 10Vol19No2, pp 143-148, 2005

[12] A.Y. Kusiak, D. Sunderesh, S. Heragu, Expert systems and optimization. IEEE Trans Software Engineering, vol. 15, pp.1012-1017, 1989.

[13] A. AlKhalifah, Ansari, G.A "Modeling of E-procurement System through UML using Data Mining Technique for Supplier Performance", IEEE International Conference on Software Networking(ICSN) May 23-26, in Jiju-Islan, South Korea 2016

[14] Manisha Jailia, Arti Tyagi "Data Mining: A Prediction for Performance Improvement in Online Learning Systems" International Journal of Advanced Research in Computer Science and Software Engineering, Volume 3, Issue 7, July 2013

[15] Larose, D. T., "Discovering Knowledge in Data: An Introduction to Data Mining", ISBN 0-471-66657-2, Ohn Wiley \& Sons, Inc, 2005.

[16] Romero, C., \& Ventura, S. "Educational data mining: A survey from 1995 to 2005" Expert Systems with Applications, 33, 135-146, 2007

[17] Castro, F., Vellido, A., Nebot, A., \& Mugica, F “Applying data mining techniques to e-learning problems", Studies in Computational Intelligence, 62, 183- 221, 2007

[18] A.A. Freitas. "Data Mining and Knowledge Discovery with Evolutionary Algorithms", Springer-Verlag, 2002

[19] Romero, C., Ventura, S., Pechenizky, M., Baker, R. "Handbook of Educational Data Mining" Editorial Chapman and Hall/CRC Press, Taylor \& Francis Group. Data Mining and Knowledge Discovery Series, 2010

[20] Erman. LX, Scott, A.C., and London, P.E. Separating and integrating control in a rule-based tool, In Proceedings of the IEEE Workshop on Principles of Knowledge-Based Systems (Denver. Cola. Dec.), IEEE, 37-43, 1984

[21] https://osumarion.osu.edu/assets/marion/uploads/What_Fa ctors_Influence_a_Career_Choice.pdf [Accessed on 2002-2017]

[22] Tanuja Agarwala "Factors influencing career choice of management students in India" Career Development International Vol. 13 No. 4, pp. 362-376, 2008.

[23] Parvinnia, E., et al. "Classification of EEG Signals using adaptive weighted distance nearest neighbor algorithm." 
Journal of King Saud University-Computer and Information Sciences 26.1, pp 1-6, 2014

[24] Derrac, Joaquín, Salvador García, and Francisco Herrera. "Fuzzy nearest neighbor algorithms: Taxonomy, experimental analysis and prospects." Information Sciences 260, pp 98-119, 2014

[25] Muja, Marius, and David G. Lowe. "Scalable nearest neighbor algorithms for high dimensional data" IEEE Transactions on Pattern Analysis and Machine Intelligence 36.11, pp 2227-2240, 2014

\section{Authors' Profiles}

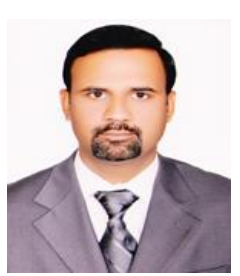

Dr. Gufran Ahamd Ansari received his Bachelor degree (B.Sc. Computer Science) from Shia P.G. College, Lucknow in 1997, MCA from DR. B.R. Ambedkar University Agra in 2002 and Ph.D. (Computer Science) from Babasaheb Bhimrao Ambedkar (A central) University, Lucknow, U.P., India in 2009 . He is currently working as an Assistant Professor in the department of Information Technology, College of Computer, Qassim University, Saudi Arabia. He has over 14 years of experience in teaching undergraduate as well as postgraduate students of Computer Science, Information Technology, and Computer Applications. He has authored more than 30 research papers on Software Engineering in leading international journals and conferences. His current research interests are Software Engineering, UML, Machine Learning, Modelling, Testing, Artificial Intelligence, Data Mining, Software Quality, and Software Security.

How to cite this paper: Gufran Ahmad Ansari,"Career Guidance through Multilevel Expert System Using Data Mining Technique", International Journal of Information Technology and Computer Science(IJITCS), Vol.9, No.8, pp.22-29, 2017. DOI: $10.5815 /$ ijitcs.2017.08.03 